\title{
Prevention of retinopathy in type 1 diabetes: a systematic review and meta-analysis
}

\author{
Sohaib Virk ${ }^{1,2^{*}}$, Kim Donaghue ${ }^{1,3}$, Tien Wong ${ }^{4}$, Maria Craig ${ }^{1,2,3}$ \\ From 8th APPES Biennial Scientific Meeting \\ Darwin, Australia. 29 October - 1 November 2014
}

Diabetic retinopathy (DR) is the most serious ocular complication of type 1 diabetes (T1D) and leading cause of acquired blindness in working aged adults. Although various interventions have been trialled to prevent the development or progression of DR, the evidence to support many of these remains unclear. We systematically reviewed the evidence for primary and secondary interventions, to guide the management of DR in people with T1D.

Systematic searches were performed using MEDLINE, EMBASE and CENTRAL databases (from January 1990 to June 2014) to identify randomised controlled trials and controlled cohort studies reporting the incidence or progression of DR following administration of systemic interventions. English-language studies with a minimum follow-up of one year were eligible. Meta-analyses of extracted data were performed to determine pooled relative risk (RR) reduction.

Twenty-three studies met the inclusion criteria. Intensive insulin therapy significantly reduced the risk of both incident DR (RR 0.44, 95\% CI 0.22-0.86, $\mathrm{p}=0.02$ ) and progression of DR (RR 0.55, 0.31-0.97, $\mathrm{p}=0.04$ ) compared with conventional therapy. Continuous subcutaneous insulin infusion (CSII) pumps provided significantly greater protection than multiple daily injection therapy (RR 0.33, 95\% CI 0.19-0.57, p<0.0001). Angiotensinconverting enzyme inhibition had no impact on DR incidence but reduced progression (RR 0.57, 95\% CI 0.34-0.94, $\mathrm{p}=0.03$ ). Conversely, angiotensin receptor blockade was effective in decreasing DR incidence ( $R R$ $0.65,95 \%$ CI 0.49-0.85, $\mathrm{p}=0.002$ ) but had non-significant effect on progression. Both pancreas-alone and combined pancreas-kidney transplantation retarded progression of DR (RR 0.20, 95\% CI 0.10-0.41, p<0.0001). Islet cell

The Children's Hospital at Westmead, Sydney, NSW, Australia Full list of author information is available at the end of the article transplantation provided no benefit compared with either intensive or conventional insulin therapy.

In people with T1D, there is strong evidence supporting intensive insulin therapy for prevention of DR. Anti-hypertensives also provide protection against DR in normotensive, normoalbuminuric adults but their effectiveness in other populations is yet to be investigated. In patients with T1D of longer duration, pancreas transplantation slows progression of DR. There is insufficient evidence to recommend the use of antilipid therapy or other medical interventions.

\section{Authors' details}

${ }^{1}$ The Children's Hospital at Westmead, Sydney, NSW, Australia. ${ }^{2}$ University of New South Wales, Sydney, NSW, Australia. ${ }^{3}$ University of Sydney, Sydney, NSW, Australia. ${ }^{4}$ Singapore Eye Research Institute, Singapore, Singapore.

Published: 28 April 2015

doi:10.1186/1687-9856-2015-S1-047

Cite this article as: Virk et al:: Prevention of retinopathy in type 1

diabetes: a systematic review and meta-analysis. International Journal of Pediatric Endocrinology 2015 2015(Suppl 1):O47.

Submit your next manuscript to BioMed Central and take full advantage of:

- Convenient online submission

- Thorough peer review

- No space constraints or color figure charges

- Immediate publication on acceptance

- Inclusion in PubMed, CAS, Scopus and Google Scholar

- Research which is freely available for redistribution 